\title{
Sighting of a Leucistic House Crow Corvus splendens Vieillot, 1817 in Bastar Plateau, Chhattisgarh, India
}

\section{Sushil Kumar Dutta}

Government KPG College, Jagdalpur, Distt. Bastar, Chhattisgarh, 494001, Chhattisgarh

\section{Introduction:}

Plumage aberrations are not uncommon in birds, but there is some confusion in the literature, especially in relation to albinos (Guay, 2012). Leucism from the Greek leukos (for 'white'), can be defined as the partial or total lack of melanin both in feathers and skin. Leucistic birds have normal eye colour and normally coloured bills and feet (van Grouw 2013, Mahabal et al., 2015, 2016).

One morning in the winters of 2020- 2021; I was on my way to birding when I was informed by villagers about a white crow-like bird. On inquiry; it was clear that it was a leucistic crow. This information made me vigilant and photographed on the 24th of April 2021 (at 7:48 am). The crow was spotted a few more times in flock and solitude. The bird was feeding with normal house crows on leftover food, in the backyards. Unlike the total albinos, this guy has black or normally coloured bills and legs. Feathers of the rest of the parts have a mix of white and grey. The head, nape, throat and breast are grey while the feathers are dull white. The front part of the forehead, lores and bill's posterior parts were brownish.

The area of its habitat comes under municipality; semiurban with mud houses, pucca government quarters and large buildings. It feeds largely on refuse around human habitations. The leusistic creature's flight ranges in about $0.5 \mathrm{~km}$ radius from the mentioned coordinates.

The area is occupied by various large trees like Mangifera indica, Cocos nucifera, Tamarindus indica, Madhuca longifolia, Azadirachta indica and Eucalyptus sp. The area has a nearby wetland, a dammed lake the Dalpat Sagar. Overall the area makes a suitable habitat for many of the bird species. One can spot both Jungle crows and house crows hereand now even the white crow!

Luckily my residence is located within the radius of the bird's range thereby providing me and our family members the luxury of watching it closely frequently. Large trees serve as resting and perching spots for the bird. With careful listening it is possible to, distinguish the sound of leucistic crows from the normal crows; however, confirmation with proper sound recording devices is
Study Area: Bastar, Chhattisgarh, India

Coordination: $19.097^{\circ} \mathrm{N}, 81.999^{\circ} \mathrm{E}$

Keywords: Flora, Redescription, Menal Waterfall

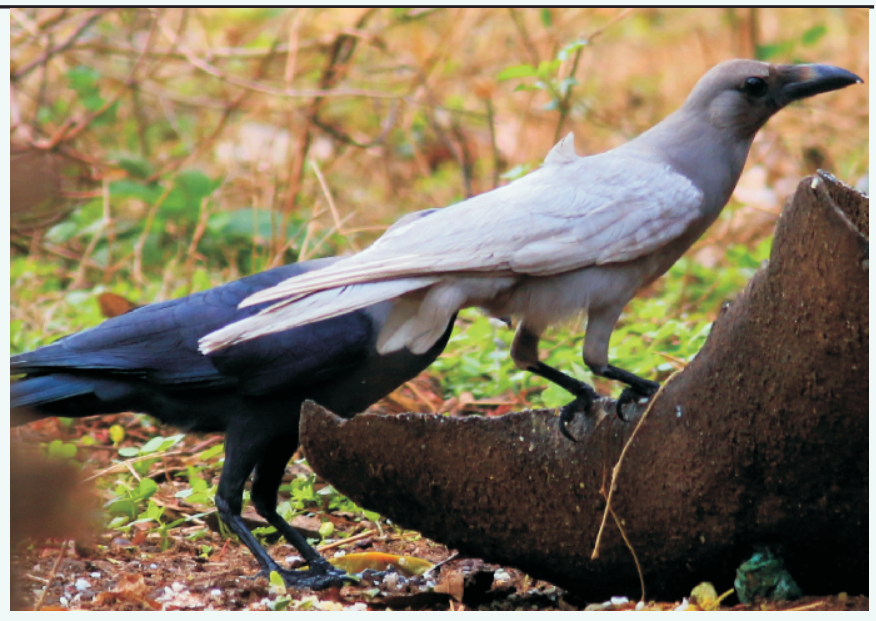

required. This is the first report of the presence of a leucistic crow in the city of Jagdalpur and in the state of Chhattisgarh state.

Colour aberrant house crows are rare. Further studies on the occurrence of this form in other parts of Chhattisgarh as well as its genetic studies are suggested to understand the frequency and type of colour aberration. This is because it is a large species with a typical colour, there is hardly any chance of it going unnoticed and harassment or persecution by children and others cannot bedenied.

Acknowledgement:

Thanks to Dr M.L.Naik for formating the first draft of this paper.

\section{References:}

Guay, P-J., Potvin, D.A. \& Robinson. R.A (2012): Aberrations in plumage coloration in birds. Aus. Field Ornithol., 29(1):23-30.

van Grouw, H. (2013): What colour is that bird? The causes and recognition of common colour aberrations in birds. Br. Birds, 106:17-29.

Mahabal, A., Sharma, R.M., \& Sayyed, A. (2015): Colour aberrations in Indian birds. Birding ASIA, 24:119-121

Mahabal, A., van Grouw, H., Sharma, R.M. \& Thakur, S. (2016): How common is albinism really? Colour aberrations in Indian birds reviewed. Dutch Bird., 38:301-309. 